\title{
Peningkatan Kemampuan Guru dalam Memanfaatkan Lingkungan Sekolah Sebagai Sumber Belajar Melalui Supervisi Akademik di SMK Sabilal Muhtadin Balikpapan
}

\author{
Suharlena \\ Pengawas SMK \\ Dinas Pendidikan Kota Balikpapan \\ Jl.Ruhui Rahayu Balikpapan \\ Email: Suharlena@yahoo.co.id
}

\begin{abstract}
The research is designed in the form of action research school with two cycles, with each cycle was carried out in two three meetings. The subjects of this study were teachers at SMK Sabilal Muhtadin Balikpapan consisting of eight teachers with different subjects. In the first cycle the average value obtained from the attitude of the teachers discuss through academic supervision is 79.38 category "enough", while the second cycle of the average value obtained was 84.88, the category "good", the average value of the obtained from the assessment of learning scenarios in the first cycle is 78.75, the category of "enough", while the second cycle of the average value obtained was 82.08, the category "good", Seeing the average value obtained from the analysis, we can conclude that from the first cycle to the second cycle, an increase in value the average obtained from each of the components that are observed and assessed, which means coaching and guidance through academic supervision can improve the ability of teachers to utilize the school environment as a learning resource.
\end{abstract}

Keywords : the ability of teachers, academic supervision

\begin{abstract}
Abstrak
Penelitian ini dirancang dalam bentuk Penelitian Tindakan Sekolah yang dilaksanakan dalam dua siklus, dimana setiap siklusnya dilaksanakan dalam dua sampai tiga kali pertemuan. Adapun subyek penelitian ini adalah guru-guru di SMK Sabilal Muhtadin Balikpapan yang terdiri dari delapan orang guru dengan mata pelajaran berbeda-beda. Pada siklus I nilai rata-rata yang diperoleh dari sikap guru berdiskusi melalui supervise akademik adalah 79,38 kategori “cukup”, sedangkan pada siklus II nilai rata-rata yang diperoleh adalah 84,88 , kategori "baik”, nilai rata-rata yang diperoleh dari penilaian scenario pembelajaran pada siklus I yaitu 78,75,kategori "cukup”, sedangkan pada siklus II nilai rata-rata yang diperoleh adalah 82,50, nilai rata-rata yang diperoleh dari penilaian pelaksanaan pembelajaran pada siklus I yaitu 78,33, kategori "cukup" ,sedangkan pada siklus II nilai rata-rata yang diperoleh adalah 82,08, kategori "baik". Melihat nilai rata-rata yang diperoleh dari hasil analisis tersebut dapat disimpulkan bahwa dari siklus I ke siklus II, terjadi peningkatan nilai rata-rata yang diperoleh dari masing-masing komponen yang diobservasi maupun yang dinilai,yang berarti pembinaan dan bimbingan melalui supervise akademik dapat meningkatkan kemampuan guru dalam memanfaatkan lingkungan sekolah sebagai sumber belajar.
\end{abstract}

Kata kunci : kemampuan guru, supervise akademik

\section{Pendahuluan}

Dari hasil pemantauan peneliti selaku pengawas sekolah, selama ini guru masih sangat jarang memanfaatkan lingkungan sekolah sebagai sumber belajar. Lingkungan sekolah tidak lebih hanya digunakan sebagai tempat bermainmain siswa pada saat istirahat. Dari wawancara yang dilakukan peneliti, sebagian besar guru mengaku enggan mengajak siswa belajar di luar kelas, karena alasan susah mengawasi. Selain itu ada guru yang menyampaikan bahwa mereka tidak bisa dan tidak tahu dalam memanfaatkan lingkungan sekolah sebagai sumber belajar.

Untuk mengatasi hal itu perlu adanya diskusi diantara para guru melalui supervise akademik yang dilakukan oleh pengawas sekolah dalam masalah 
pemanfaatan lingkungan sekolah sebagai sumber belajar. Dalam kegiatan diskusi tersebut para guru bisa membagi pengalaman dalam pemanfaatan lingkungan sekolah sebagai sumber belajar untuk mencapai hasil belajar yang optimal. Penelitian Nur Mohamad dalam Ekowati (2001) menunjukkan diskusi kolompok memiliki dampak yang amat positif bagi guru yang tingkat pengalamannya rendah maupun yang tingkat pengalamannya tinggi.

Berdasarkan hal tersebut di atas, serta hasil pengamatan peneliti melalui supervisi, maka dapat diidentifikasi masalahnya sebagai berikut:

1. Pendekatan pembelajaran lebih banyak didominasi oleh peran guru, dan guru satu-satunya sumber belajar,selain buku paket.

2. Pembelajaran yang dikembangkan di kelas - kelas kelihatannya lebih ditekankan pada pemikiran reproduktif, menekankan pada hafalan dan mencari satu jawaban benar terhadap soal-soal yang diberikan

3. Dalam kegiatan pembelajaran guru belum mampu menerapkan model, motode atau strategi pembelajaran yang sesuai dengan karakteristik materi yang diajarkan sehingga kurang mengembangkan daya nalar siswa secara optimal.

Berdasarkan identifikasi masalah diatas,maka dalam penelitian tindakan sekolah ini difokuskan pada penelitian masalah memanfaatkan lingkungan sekolah sebagai sumber belajar yang dapat dirumuskan sebagai berikut :

Apakah kemampuan guru dalam memanfaatkan lingkungan sekolah sebagai sumber belajar dapat ditingkatkan melalui supervise akademik di SMK Sabilal Muhtadin Balikpapan?

Tujuan penelitian ini adalah

a. Untuk meningkatkan kemampuan guru dalam memanfaatkan lingkungan sekolah sebagai sumber belajar melalui supervise akademik di SMK Sabilal Muhtadin Balikpapan.

b. Guru, dapat menyempurnakan metode pembelajaran yang diterapkan di sekolah sehingga dapat meningkatkan kreativiats, motivasi dan hasil belajar siswa.

A. Pemanfaatan Lingkungan Sekolah sebagai Sumber Belajar

Nilai-nilai kegunaan sumber belajar masyarakat adalah : (1) menghubungkan kurikulum dengan kegiatan-kegiatan masyarakat akan mengembangkan kesadaran dan kepekaan terhadap masalah sosial; (2) menggunakan minat-minat pribadi peserta didik akan menyebabkan belajar lebih bermakna baginya; (3) mempelajari kondisi-kondisi masyarakat merupakan latihan berpikir ilmiah (scientif methode); (4) mempelajari masyarakat akan memperkuat dan memperkaya kurikulum melalui pelaksanaan praktis didalam situasi sesungguhnya; (5) peserta didik memperoleh pengalaman langsung yang kongkrit, realistis dan verbalisme. (Douglas dan Mill dalam Rusyan (2001) : 152)

Pemanfaatan lingkungan sekolah sebagai sumber belajar mengarahkan anak pada peristiwa atau keadaan yang sebenarnya atau keadaan yang alami sehingga lebih nyata, lebih faktual dan kebenarannya lebih dapat dipertanggungjawabkan.

Manfaat nyata yang dapat diperoleh dengan memanfaatkan lingkungan ini adalah : (1) menyediakan berbagai hal yang dapat dipelajari anak, (2) memungkinkan terjadinya proses belajar yang lebih bermakna (meaningful learning), (3) memungkinkan terjadinya proses pembentukan kepribadian anak, (4) kegiatan belajar akan lebih menarik bagi anak, dan (5) menumbuhkan aktivitas belajar anak (learning aktivities). (Badru Zaman, dkk. 2005)

B. Pengertian Supervisi 
Dalam kaitannya dengan supervisi yang dilakukan oleh Kepala Sekolah, Menurut (Purwanto, 2004:32). Pengertian supervisi adalah "suatu aktivitas pembinaan yang direncanakan untuk membantu para guru dan pegawai sekolah lainnya dalam melakukan pekerjaan mereka secara efektif' Menurut Jones dalam Mulyasa (2003:155), supervisi merupakan "bagian yang tidak terpisahkan dari seluruh proses administrasi pendidikan yang ditujukan terutama untuk mengembangkan efektivitas kinerja personalia sekolah yang berhubungan tugas-tugas utama pendidikan". Menurut Carter dalam Sahertian (2000:17) supervisi adalah "usaha dari petugas-petugas sekolah dalam memimpin guru-guru dan petugas-petugas lainnya dalam memperbaiki pengajaran, termasuk menstimulasi, menyeleksi pertumbuhan jabatan dan perkembangan guru-guru serta merevisi tujuan-tujuan pendidikan, bahan pengajaran dan metode serta evaluasi pengajaran".

Supervisi adalah aktivitas menentukan kondisi/syarat-syarat yang essensial yang akan menjamin tercapainya tujuan-tujuan pendidikan. Dari definisi tersebut maka tugas kepala sekolah sebagai supervisor berarti bahwa dia hendaknya pandai meneliti, mencari, dan menentukan syarat-syarat mana sajakah yang diperlukan bagi kemajuan sekolahnya sehingga tujuan-tujuan pendidikan di sekolah itu semaksimal mungkin dapat tercapai.

C. Karakteristik Supervisi

Menurut Mulyasa (2004:112) Salah satu supervisi akademik yang populer adalah supervisi klinis, yang memiliki karakteristik sebagai berikut:

1. Supervisi diberikan berupa bantuan (bukan perintah), sehingga inisiatif tetap berada di tangan tenaga kependidikan.

2. Aspek yang disupervisi berdasarkan usul guru, yang dikaji bersama kepala sekolah sebagai supervisor untuk dijadikan kesepakatan.
3. Instrumen dan metode observasi dikembangkan bersama oleh guru dan Kepala Sekolah.

4. Mendiskusikan dan menafsirkan hasil pengamatan dengan mendahulukan interpretasi guru.

5. Supervisi dilakukan dalam suasana terbuka secara tatap muka, dan supervisor lebih banyak mendengarkan serta menjawab pertanyaan guru daripada memberi saran dan pengarahan.

6. Supervisi klinis sedikitnya memiliki tiga tahap, yaitu pertemuan awal, pengamatan, dan umpan balik.

7. Adanya penguatan dan umpan balik dari kepala sekolah sebagai supervisor terhadap perubahan perilaku guru yang positif sebagai hasil pembinaan.

8. Supervisi dilakukan secara berkelanjutan untuk meningkatkan suatu keadaan dan memecahkan suatu masalah.

Dari uraian di atas dapat disimpulkan bahwa supervisi klinis lebih berorientasi kepada penemuan masalah secara obyektif. Masalah tersebut bukan untuk menekan bawahan,akan tetapi untuk dianalisis dan dilakukan pemecahan masalah (problem solving) secara bersama-sama.

\section{Metode Penelitian}

Metoda yang dipakai dalam penelitian ini berupa langkah tindakan.

Bentuk tindakan dalam penelitian ini berupa supervisi (bimbingan kelompok) kepada guru-guru melalui diskusi supervisi dengan pengawas sekolah, agar mampu menyusun skenario pembelajaran dan pelaksanaan pembelajaran dengan memanfaatkan lingkungan sekolah sebagai sumber belajar secara efektif. Secara rinci bentuk tindakan dalam penelitian ini adalah :

1.Menyampaikan informasi tentang pemanfaatan lingkungan sekolah sebagai sumber belajar.

2.Membimbing guru menyusun skenario pembelajaran yang berkaitan dengan 
pemanfaatan lingkungan sekolah sebagai sumber belajar.

3.Membimbing guru dalam memanfaatkan lingkungan sekolah sebagai sumber belajar.

4.Membimbing guru dalam melaksanakan pembelajaran dengan memanfaatkan lingkungan sekolah sebagai sumber belajar.

Prosedur penelitian yang dilakukan adalah menggunakan model penelitian tindakan sekolah yang dikembangkan oleh Kemmis \& Taggart (2000), dimana pada prinsipnya ada empat tahap kegiatan yaitu, perencanaan tindakan (planning), pelaksanaan tindakan (action), observasi dan evaluasi proses tindakan (observation and evaluation) dan melakukan refleksi (reflecting).

Alur penelitian secara keseluruhan dapat digambarkan sebagai berikut :

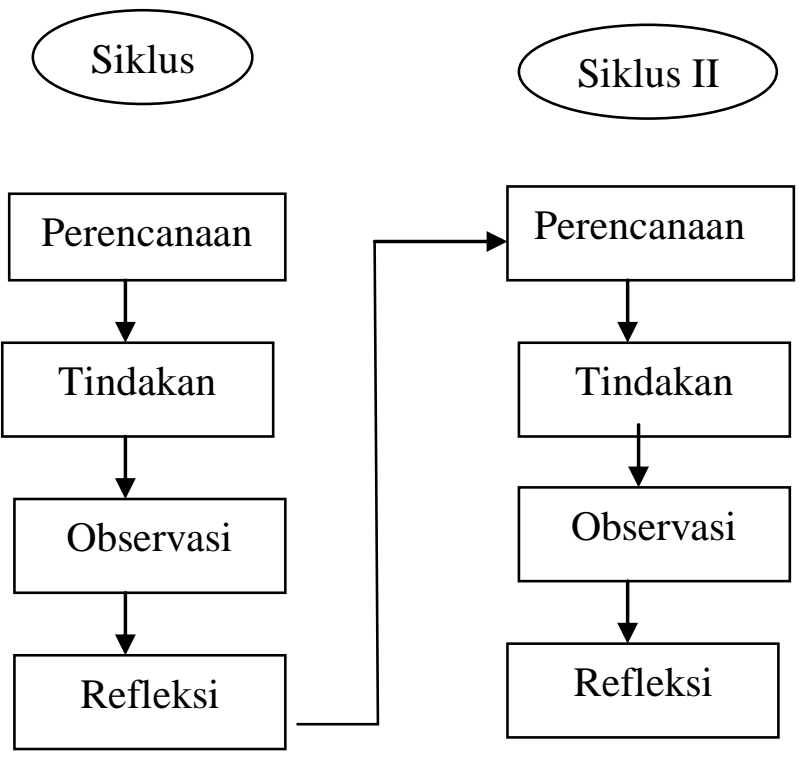

Gambar 3.1. Alur Penelitian

Pelaksanaan Tindakan.

\section{Siklus I}

a. Perencanaan penelitian meliputi:

1). Pertemuan dengan Kepala Sekolah dan guru - guru, menginformasikan tentang pelaksanaan penelitian.
2). Peneliti menyiapkan skenario diskusi kelompok yang akan dilaksanakan selama proses tindakan.

3). Peneliti menyiapkan instrumen penelitian ( lembar observasi, lembar penilaian kemampuan guru).

b. Pelaksanaan Penelitian.

Pada tahap pelaksanaan merupakan tahap inti dimana pelaksanaan supervisi berlangsung dengan langkah-langkah berikut.

1). Pertemuan I

a). Peneliti selaku pengawas sekolah memberi arahan umum pemanfaatan lingkungan sekolah sebagai sumber belajar

2). Pertemuan II

a). Guru melaksanakan pembelajaran dengan memanfaatkan lingkungan sekolah sebagai sumber belajar sesuai skenario pembelajaran yang dimiliki.

b). Peneliti melakukan penilaian pada guru terkait dengan implementasi pembelajaran sesuai skenario yang dibuat.

3). Pertemuan III

a). Pengawas sekolah dalam supervisi akademik melakukan diskusi tentang kendala-kendala pelaksanakan pembelajaran dengan memanfaatkan lingkungan sekolah sebagai sumber belajar.

b). Peneliti melakukan bimbingan dalam kelompok, terkait dengan pembelajaran yang diterapkan guru. dan merevisi skenario pembelajaran sehingga menghasilkan skenario pembelajaran yang sesuai dengan pakem.

c. Observasi dan Evaluasi

Kegiatan observasi dilaksanakan bersamaan dengan pelaksanaan tindakan yaitu pada saat supervisi baik pada pertemuan I, II dan III.

Tahap observasi bertujuan untuk mengetahui kerjasama, kreativitas, perhatian, maupun presentasi yang dilakukan guru dalam menyusun skenario pembelajaran maupun dalam 
melaksanakan pembelajaran dengan memanfaatkan lingkungan sekolah sebagai sumber belajar. Pelaksanaan observasi dilakukan dengan menggunakan lembar observasi.

\section{d. Refleksi}

Berdasarkan hasil observasi selama berlangsungnya kegiatan dan hasil evaluasi pada akhir pertemuan siklus dilakukan refleksi. Hasil refleksi ini dijadikan acuan untuk merencanakan penyempurnaan dan perbaikan siklus berikutnya. Semua tahap kegiatan tersebut mulai dari tahap perencanaan, pelaksanaan maupun observasi dan evaluasi dilakukan secara berulang-ulang melalui siklussiklus sampai ada peningkatan sesuai yang diharapkan yaitu mencapai angka katagori "baik" dengan rentang skor 80 - 89. Jika skor yang diperoleh kurang dari 80-89, berarti belum memenuhi target yang ditetapkan, maka perlu bimbingan pada siklus II.

2. Siklus II

a. Perencanaan Penelitian.

Pada tahap ini direncanakan supervisi (pembinaan) dengan menggunakan tehnik diskusi, tentang pemanfaatan lingkungan sekolah sebagai sumber belajar oleh guru kelas maupun guru bidang studi di SMK Sabilal Muhtadin Balikpapan yang belum mencapai hasil optimal dalam siklus I.

Berdasarkan hasil observasi dan refleksi siklus I,dilakukan perbaikan terhadap strategi dan penyempurnaan pelaksanaan bimbingan di siklus II.

b. Pelaksanaan Penelitian.

Pada prinsipnya langkah-langkah pelaksanaan tindakan pada siklus I diulang pada siklus II dengan memodifikasi dan perbaikan-perbaikan berdasarkan hasil refleksi pada siklus I.

Kegiatan pada siklus II terdiri dari 2 (dua) kali pertemuan dengan mengikuti langkahlangkah sebagai berikut :

\section{1). Pertemuan I}

a). Melalui supervisi, guru mendiskusikan tentang permasalahanpermasalahann atau hambatan memanfaatkan lingkungan sekolah sebagai sumber belajar,dalam menyusun skenario pembelajaran yang selanjutnya dicarikan pemecahannya. Kegiatan ini dibantu oleh guru yang dianggap sudah cukup mampu dalam hal tersebut..

b). Guru mempresentasikan dan mensimulasikan hasil diskusi kelompoknya.

c). Guru merevisi dan menyempurnakan skenario pembelajaran dengan mengoptimalkan pemanfaatan lingkungan sekolah sebagai sumber belajar.

\section{2). Pertemuan II}

a). Guru melaksanakan kegiatan belajar mengajar di kelas dengan menggunakan skenario pembelajaran yang sudah direvisi. b).Guru mendiskusikan dan menyempurnakan skenario pembelajaran yang lengkap dengan pemanfaatan lingkungan sekolah sebagai sumber belajar.

c).Guru mencatat kekurangan pembelajaran yang perlu diperbaiki dan disempurnakan.

c. Observasi dan Evaluasi.

Observasi dilakukan peneliti saat guru berdiskusi tentang masalah atau hambatan dan pemecahannya dalam kegiatan kelompok kerja guru baik secara individu maupun kelompok.Observasi terhadap aspek sikap guru dilakukan dengan menggunakan format observasi yang sama dengan format observasi yang digunakan pada siklus I.

Evaluasi dilakukan pada akhir pertemuan siklus II,dengan menggunakan format penilaian yang sama dengan format penilaian yang digunakan pada siklus I. Adapun aspek yang dinilai, serta cara menilai juga sama dengan penilaian pada siklus I.

d. Refleksi

Berdasarkan hasil observasi selama berlangsungnya kegiatan dan hasil evaluasi pada akhir pertemuan siklus II,maka dilanjutkan dengan mengadakan 
refleksi terhadap kegiatan dan hasil kegiatan yang sudah berlangsung.

\section{Hasil Penelitian}

\section{Siklus I}

Kegiatan dalam siklus I ini, diawali dengan kegiatan diskusi metode pembelajaran oleh pengawas sekolah tentang permasalahan yang dihadapi dalam pemanfaatan lingkungan sekolah sebagai sumber belajar, dilanjutkan dengan informasi tentang manfaat lingkungan sekolah sebagai sumber belajar bagi siswa dan implementasinya dalam proses belajar mengajar.

Saat guru berdiskusi dengan pengawas sekolah pada siklus I, peneliti mengadakan observasi tentang sikap guru dalam berdiskusi yang hasilnya sebagai berikut :

Tabel. 1. Data Hasil Observasi

\begin{tabular}{|c|c|c|c|c|c|c|c|}
\hline \multirow{3}{*}{ No } & \multirow{3}{*}{ Nama Guru } & \multicolumn{4}{|c|}{ Aspek yang diobservasi } & \multirow{3}{*}{$\begin{array}{l}\text { Jumlah } \\
\text { Skor } \\
\text { Mak. } \\
100\end{array}$} & \multirow{3}{*}{$\begin{array}{l}\text { Ka } \\
\text { ta } \\
\text { Go } \\
\text { ri }\end{array}$} \\
\hline & & $\begin{array}{c}\text { Kerj } \\
\text { asa } \\
\text { ma }\end{array}$ & $\begin{array}{l}\text { Aktivit } \\
\text { as }\end{array}$ & $\begin{array}{c}\text { erhatia } \\
\mathrm{n}\end{array}$ & $\begin{array}{l}\text { Prese } \\
\text { ntasi }\end{array}$ & & \\
\hline & & $\begin{array}{l}(1- \\
10 \\
)\end{array}$ & $\begin{array}{c}(1 \\
- \\
40 \\
)\end{array}$ & $\begin{array}{l}(1- \\
20)\end{array}$ & $\begin{array}{c}(1- \\
30 \\
)\end{array}$ & & \\
\hline 1 & $\begin{array}{l}\text { Eka } \\
\text { Oktavianti,S.P } \\
\text { d }\end{array}$ & 8 & 30 & 15 & 27 & 80 & $\mathrm{~B}$ \\
\hline 2 & $\begin{array}{l}\text { Madinatul } \\
\text { Munawarah,S } \\
\text {.Pd }\end{array}$ & 8 & 30 & 16 & 26 & 80 & $\mathrm{~B}$ \\
\hline 3 & Marliyah ,ST & 8 & 30 & 15 & 27 & 80 & $\mathrm{~B}$ \\
\hline 4 & Nudia,S.Pd & 8 & 30 & 15 & 27 & 80 & $\mathrm{~B}$ \\
\hline 5 & Syahrudin,SE & 8 & 31 & 16 & 26 & 81 & $\mathrm{~B}$ \\
\hline 6 & $\begin{array}{l}\text { Bahsan Aidi } \\
\text {,S.Pd }\end{array}$ & 8 & 33 & 16 & 22 & 79 & $\mathrm{C}$ \\
\hline 7 & Hamidah & 8 & 29 & 18 & 23 & 78 & $\mathrm{C}$ \\
\hline 8 & Nor Ainah & 8 & 30 & 14 & 25 & 77 & $\mathrm{C}$ \\
\hline & Jumlah & 64 & $\begin{array}{c}24 \\
3\end{array}$ & 125 & $\begin{array}{c}20 \\
3\end{array}$ & 635 & \\
\hline & Rata-rata & $\begin{array}{c}8.0 \\
0\end{array}$ & $\begin{array}{l}30 . \\
38\end{array}$ & $\begin{array}{c}15.6 \\
3\end{array}$ & $\begin{array}{l}25 . \\
38\end{array}$ & $\begin{array}{c}79.3 \\
8\end{array}$ & $\mathrm{C}$ \\
\hline
\end{tabular}

Tabel.2. Data Hasil Penilaian Skenario Pembelajaran

\begin{tabular}{|c|l|c|c|c|c|c|c|c|}
\hline \multirow{2}{*}{ No } & \multirow{2}{*}{ Nama Guru } & \multicolumn{3}{|c|}{$\begin{array}{c}\text { Aspek yang } \\
\text { dinilai }\end{array}$} & \multirow{2}{*}{$\begin{array}{c}\text { Jumlah } \\
\text { Skor }\end{array}$} & $\begin{array}{c}\text { Jumlah } \\
\text { Nilai }\end{array}$ & Katagori \\
\cline { 2 - 8 } & 1 & 2 & 3 & 4 & & & \\
\hline 1 & $\begin{array}{l}\text { Eka } \\
\text { Oktavianti,S.Pd }\end{array}$ & 4 & 4 & 4 & 5 & 17 & 85 & B \\
\hline 2 & $\begin{array}{l}\text { Madinatul } \\
\text { Munawarah,S.P }\end{array}$ & 5 & 4 & 4 & 3 & 16 & 80 & B \\
\hline
\end{tabular}

\begin{tabular}{|c|c|c|c|c|c|c|c|c|}
\hline & $\mathrm{d}$ & & & & & & & \\
\hline 3 & Marliyah ,ST & 5 & 4 & 3 & 5 & 17 & 85 & B \\
\hline 4 & Nudia,S.Pd & 4 & 4 & 4 & 5 & 17 & 85 & B \\
\hline 5 & Syahrudin,SE & 4 & 4 & 3 & 4 & 15 & 75 & $\mathrm{C}$ \\
\hline 6 & $\begin{array}{l}\text { Bahsan Aidi } \\
\text {,S.Pd }\end{array}$ & 4 & 4 & 3 & 4 & 15 & 75 & C \\
\hline 7 & Hamidah & 4 & 3 & 3 & 3 & 13 & 65 & $\mathrm{C}$ \\
\hline 8 & Nor Ainah & 5 & 4 & 3 & 4 & 16 & 80 & B \\
\hline & Jumlah & $\begin{array}{l}3 \\
4 \\
\end{array}$ & $\begin{array}{l}3 \\
1\end{array}$ & $\begin{array}{l}2 \\
8 \\
\end{array}$ & $\begin{array}{l}3 \\
3 \\
\end{array}$ & 126 & 630 & \\
\hline & Rata-rata & $\begin{array}{l}4 \\
2 \\
5\end{array}$ & $\begin{array}{l}3 \\
8 \\
8 \\
8\end{array}$ & $\begin{array}{l}3 \\
5 \\
5 \\
0\end{array}$ & $\begin{array}{l}4 \\
1 \\
3\end{array}$ & 15.75 & 78.75 & $\mathrm{C}$ \\
\hline
\end{tabular}

Tabel.3. Data Hasil Penilaian Pelaksanaan Pembelajaran

\begin{tabular}{|c|c|c|c|c|c|c|c|c|c|c|}
\hline \multirow[b]{2}{*}{ No } & \multirow[b]{2}{*}{ Nama Guru } & \multicolumn{6}{|c|}{ Aspek yang dinilai } & \multirow{2}{*}{$\begin{array}{l}\text { Jum } \\
\text { lah } \\
\text { Sk } \\
\text { or }\end{array}$} & \multirow{2}{*}{$\begin{array}{c}\mathrm{Ju} \\
\mathrm{ml} \\
\mathrm{ah} \\
\text { Nilai }\end{array}$} & \multirow{2}{*}{$\begin{array}{l}\mathrm{Ka} \\
\operatorname{tag} \\
\text { ori }\end{array}$} \\
\hline & & 1 & 2 & 3 & 4 & 5 & 6 & & & \\
\hline 1 & $\begin{array}{l}\text { Eka } \\
\text { Oktavianti, } \\
\text { S.Pd }\end{array}$ & 5 & 4 & 5 & 4 & 4 & 4 & 26 & $\begin{array}{l}86 . \\
67\end{array}$ & B \\
\hline 2 & $\begin{array}{l}\text { Madinatul } \\
\text { Munawarah } \\
\text {,S.Pd }\end{array}$ & 4 & 3 & 4 & 4 & 3 & 4 & 22 & $\begin{array}{l}73 . \\
33\end{array}$ & $\mathrm{C}$ \\
\hline 3 & $\begin{array}{l}\text { Marliyah } \\
\text {,ST }\end{array}$ & 5 & 4 & 4 & 4 & 5 & 5 & 27 & $\begin{array}{l}90 . \\
00\end{array}$ & A \\
\hline 4 & Nudia,S.Pd & 4 & 3 & 4 & 4 & 3 & 4 & 22 & $\begin{array}{l}73 . \\
33\end{array}$ & $\mathrm{C}$ \\
\hline 5 & $\begin{array}{l}\text { Syahrudin, } \\
\text { SE }\end{array}$ & 4 & 3 & 4 & 3 & 4 & 3 & 21 & $\begin{array}{l}70 . \\
00\end{array}$ & $\mathrm{C}$ \\
\hline 6 & $\begin{array}{l}\text { Bahsan } \\
\text { Aidi ,S.Pd }\end{array}$ & 5 & 4 & 4 & 4 & 4 & 5 & 26 & $\begin{array}{l}86 . \\
67\end{array}$ & B \\
\hline 7 & Hamidah & 4 & 3 & 3 & 4 & 3 & 3 & 20 & $\begin{array}{l}66 . \\
66\end{array}$ & $\mathrm{C}$ \\
\hline 8 & Nor Ainah & 4 & 4 & 4 & 4 & 4 & 4 & 24 & $\begin{array}{l}80 . \\
00\end{array}$ & B \\
\hline Jum & & 34 & 28 & 32 & $\begin{array}{l}3 \\
2\end{array}$ & 30 & 32 & $\begin{array}{c}18 \\
8\end{array}$ & $\begin{array}{c}62 \\
6.6 \\
7\end{array}$ & \\
\hline & Rata-rata & 4.25 & 3.5 & 4 & 4 & 3.75 & 4 & 23.5 & 78.33 & $\mathrm{C}$ \\
\hline
\end{tabular}

\section{Siklus II.}

Pada siklus II, kegiatan yang dilaksanakan adalah mendiskusikan hambatanhambatan yang dialami dalam menyusun skenario pembelajaran dan pelaksanaan pembelajaran di kelas pada siklus I melalui supervise akademik yang dilakukan pengawas sekolah. Dalam penyusunan skenario pembelajaran khususnya pada aspek 1, 2 dan 4 guru melakukan revisi, dipandu oleh guru yang sudah mampu,dengan bimbingan peneliti/pengawas. Dalam pelaksanaan pembelajaran di kelas,terkait dengan hambatan pada aspek 1. kegiatan awal, aspek 2. kegiatan inti, aspek 3 . kemampuan guru mengkaitkan materi 
pelajaran dengan lingkungan sekolah ,dan aspek 6. penutup pelajaran, maka guru mendiskusikan kembali hambatan tersebut dalam supervisi dibimbing pengawas sebagai peneliti. Sebelum pelaksanaan pembelajaran di kelas, terlebih dahulu dilakukan simulasi atau modeling dengan menggunakan anggota kelompok guru sebagai siswa.

Sebagaimana kegiatan peneliti pada siklus I, maka kegiatan pada siklus keduapun dilakukan observasi,evaluasi dan penilaian.

Tabel. 4. Data Hasil Observasi

\begin{tabular}{|c|c|c|c|c|c|c|c|}
\hline \multirow{5}{*}{ No } & \multirow{5}{*}{ Nama Guru } & \multicolumn{4}{|c|}{ Aspek yang diobservasi } & \multirow{5}{*}{$\begin{array}{c}\text { Jumla } \\
\text { h } \\
\text { Skor } \\
\text { Mak. } \\
100\end{array}$} & \multirow{5}{*}{$\begin{array}{c}\mathrm{Ka} \\
\text { ta } \\
\mathrm{Go} \\
\text { ri }\end{array}$} \\
\hline & & Kerjas & Aktivi & Perhatia & Prese & & \\
\hline & & $(1-$ & $(1$ & $(1-$ & $(1-$ & & \\
\hline & & 10) & $\begin{array}{l}- \\
40\end{array}$ & 20) & 30 & & \\
\hline & & & ) & & & & \\
\hline \multirow[t]{2}{*}{1} & Eka & & & & & & \\
\hline & $\begin{array}{l}\text { Oktavianti,S. } \\
\text { Pd }\end{array}$ & 8 & 35 & 15 & 28 & 86 & B \\
\hline \multirow[t]{2}{*}{2} & Madinatul & & & & & & \\
\hline & $\begin{array}{l}\text { Munawarah,S } \\
\text {.Pd }\end{array}$ & 8 & 33 & 16 & 26 & 83 & B \\
\hline 3 & Marliyah ,ST & 8 & 38 & 18 & 28 & 92 & A \\
\hline 4 & Nudia,S.Pd & 8 & 35 & 15 & 27 & 85 & $\mathrm{~B}$ \\
\hline 5 & Syahrudin,SE & 8 & 32 & 16 & 26 & 82 & $\mathrm{~B}$ \\
\hline 6 & Bahsan Aidi & 8 & 33 & 16 & 26 & 83 & $\mathrm{~B}$ \\
\hline 7 & Hamidah & 8 & $\begin{array}{l}55 \\
36\end{array}$ & 10 & 20 & $\frac{05}{86}$ & B \\
\hline 8 & Nor Ainah & 8 & 34 & 14 & 26 & 82 & $\mathrm{~B}$ \\
\hline \multirow{2}{*}{\multicolumn{2}{|c|}{ Jumlah }} & & 27 & & 21 & 67 & \\
\hline & & 64 & 6 & 125 & 4 & 9 & \\
\hline \multicolumn{2}{|r|}{ Rata-rata } & 8.00 & $\begin{array}{l}34 . \\
50\end{array}$ & $\begin{array}{c}15.6 \\
3\end{array}$ & $\begin{array}{l}26 . \\
75\end{array}$ & $\begin{array}{l}84 . \\
88\end{array}$ & B \\
\hline
\end{tabular}

Tabel.5. Data Hasil Penilaian Skenario Pembelajaran

\begin{tabular}{|c|c|c|c|c|c|c|c|c|}
\hline \multirow{2}{*}{ No } & \multirow{2}{*}{ Nama Guru } & \multicolumn{4}{|c|}{ Aspek yang dinilai } & \multirow{2}{*}{$\begin{array}{l}\mathrm{Ju} \\
\mathrm{ml} \\
\mathrm{ah} \\
\mathrm{Sk} \\
\text { or }\end{array}$} & \multirow{2}{*}{$\begin{array}{c}\mathrm{Ju} \\
\mathrm{ml} \\
\mathrm{ah} \\
\mathrm{Nil} \\
\mathrm{ai}\end{array}$} & \multirow{2}{*}{$\begin{array}{l}\mathrm{Ka} \\
\text { tag } \\
\text { ori }\end{array}$} \\
\hline & & 1 & 2 & 3 & 4 & & & \\
\hline 1 & $\begin{array}{l}\text { Eka } \\
\text { Oktavianti, } \\
\text { S.Pd }\end{array}$ & 4 & 4 & 4 & 5 & 17 & 85 & $\mathrm{~B}$ \\
\hline 2 & $\begin{array}{l}\text { Madinatul } \\
\text { Munawarah } \\
\text {,S.Pd }\end{array}$ & 5 & 4 & 4 & 4 & 17 & 85 & $\mathrm{~B}$ \\
\hline 3 & $\begin{array}{l}\text { Marliyah } \\
\text {,ST }\end{array}$ & 4 & 4 & 4 & 5 & 17 & 85 & $\mathrm{~B}$ \\
\hline 4 & Nudia,S.Pd & 4 & 4 & 4 & 5 & 17 & 85 & $\mathrm{~B}$ \\
\hline 5 & $\begin{array}{l}\text { Syahrudin, } \\
\text { SE }\end{array}$ & 4 & 4 & 4 & 4 & 16 & 80 & $\mathrm{~B}$ \\
\hline 6 & $\begin{array}{l}\text { Bahsan } \\
\text { Aidi ,S.Pd }\end{array}$ & 4 & 4 & 4 & 4 & 16 & 80 & $\mathrm{~B}$ \\
\hline 7 & Hamidah & 4 & 4 & 4 & 4 & 16 & 80 & $\mathrm{~B}$ \\
\hline 8 & Nor Ainah & 4 & 4 & 4 & 4 & 16 & 80 & $\mathrm{~B}$ \\
\hline \multicolumn{2}{|c|}{ Jumlah } & 35 & 32 & 30 & 35 & 132 & 660 & \\
\hline \multicolumn{2}{|r|}{ Rata-rata } & 4.38 & 4.00 & 3.75 & 4.38 & $\begin{array}{r}16.5 \\
0 \\
\end{array}$ & $\begin{array}{r}82.5 \\
0 \\
\end{array}$ & $\mathrm{~B}$ \\
\hline
\end{tabular}

Tabel.6. Data Hasil Penilaian Pelaksanaan Pembelajaran

\begin{tabular}{|c|c|c|c|c|c|c|c|c|c|c|}
\hline \multirow[b]{2}{*}{ No } & \multirow[b]{2}{*}{$\begin{array}{c}\text { Nama } \\
\text { Guru }\end{array}$} & \multicolumn{6}{|c|}{ Aspek yang dinilai } & \multirow{2}{*}{$\begin{array}{c}\text { Ju } \\
\mathrm{ml} \\
\text { ah } \\
\text { Sk } \\
\text { or }\end{array}$} & \multirow{2}{*}{\begin{tabular}{|c|}
$\mathrm{Ju}$ \\
$\mathrm{ml}$ \\
$\mathrm{ah}$ \\
$\mathrm{Nil}$ \\
$\mathrm{ai}$ \\
\end{tabular}} & \multirow[b]{2}{*}{$\begin{array}{l}\text { Ka } \\
\text { tag } \\
\text { ori }\end{array}$} \\
\hline & & 1 & 2 & 3 & 4 & 5 & 6 & & & \\
\hline 1 & $\begin{array}{l}\text { Eka } \\
\text { Oktaviant } \\
\text { i,S.Pd }\end{array}$ & 5 & 4 & 5 & 4 & 4 & 4 & 26 & $\begin{array}{l}86 . \\
67\end{array}$ & B \\
\hline 2 & $\begin{array}{l}\text { Madinatu } \\
1 \\
\text { Munawar } \\
\text { ah,S.Pd }\end{array}$ & 4 & 4 & 4 & 4 & 4 & 4 & 24 & $\begin{array}{l}80 . \\
00\end{array}$ & $\mathrm{~B}$ \\
\hline 3 & $\begin{array}{l}\text { Marliyah } \\
\text { „ST }\end{array}$ & 5 & 4 & 4 & 5 & 4 & 5 & 27 & $\begin{array}{l}90 . \\
00 \\
\end{array}$ & A \\
\hline 4 & $\begin{array}{l}\text { Nudia,S. } \\
\text { Pd }\end{array}$ & 4 & 3 & 4 & 4 & 4 & 4 & 23 & $\begin{array}{l}76 . \\
67 \\
\end{array}$ & $\mathrm{C}$ \\
\hline 5 & $\begin{array}{l}\text { Syahrudi } \\
\text { n,SE }\end{array}$ & 4 & 4 & 4 & 4 & 4 & 4 & 24 & $\begin{array}{c}80 . \\
00\end{array}$ & B \\
\hline 6 & $\begin{array}{l}\text { Bahsan } \\
\text { Aidi } \\
\text {,S.Pd }\end{array}$ & 5 & 4 & 4 & 4 & 4 & 5 & 26 & $\begin{array}{l}86 . \\
67 \\
\end{array}$ & B \\
\hline 7 & Hamidah & 4 & 4 & 4 & 4 & 4 & 4 & 24 & $\begin{array}{l}73 . \\
33 \\
\end{array}$ & $\mathrm{C}$ \\
\hline 8 & $\begin{array}{l}\text { Nor } \\
\text { Ainah }\end{array}$ & 4 & 4 & 4 & 4 & 4 & 4 & 24 & $\begin{array}{l}80 . \\
00\end{array}$ & B \\
\hline Jum & & 35 & 30 & 33 & 33 & 32 & 34 & 197 & $\begin{array}{c}656.6 \\
7 \\
\end{array}$ & \\
\hline Rat & rata & 4.38 & 3.75 & 4.13 & 4.13 & $\begin{array}{l}4 . \\
00 \\
\end{array}$ & \begin{tabular}{l|}
4. \\
25 \\
\end{tabular} & $\begin{array}{c}24.6 \\
3 \\
\end{array}$ & $\begin{array}{c}82.0 \\
8 \\
\end{array}$ & B \\
\hline
\end{tabular}

Data yang diperoleh dari observasi sikap guru pada siklus II, setelah dianalisis ada peningkatan kearah perbaikan yaitu berada pada katagori "baik", dengan rata-rata nilai 84.88. Sedangkan untuk penilaian skenario pembelajaran dan penilaian pelaksanaan pembelajaran,masing-masing juga ada peningkatan yang ke arah yang lebih baik yaitu: untuk skenario pembelajaran berada pada katagori "baik" dengan nilai rata-rata 82.50 , dan untuk penilaian pelaksanaan pembelajaran di kelas berada pada katagori "baik" dengan nilai rata-rata 82.08. Dengan melihat hasil pada siklus II, maka refleksi terhadap hasil yang diperoleh peneliti pada siklus II ini adalah adanya peningkatan kemampuan guru memanfaatkan lingkungan sekolah sebagai sumber belajar. Hal ini dibuktikan dengan nilai rata-rata yang diperoleh dalam memprogramkan pembelajaran serta dalam implementasinya di kelas yang sudah menunjukkan adanya peningkatan kemampuan guru untuk memanfaatkan lingkungan sekolah sebagai sumber belajar yang lebih baik.Sedangkan dari jumlah 
guru, $75 \%$ sudah mencapai kriteria yang ditetapkan.

Dari 8 orang guru yang terlibat, 6 orang guru sudah mendapat skor dengan katagori "baik" sedangkan 3 orang dengan katagori "cukup".Oleh karena itu dilanjutkan dengan tindakan siklus II yang hasilnya secara umum ada peningkatan ke arah yang lebih baik yaitu $75 \%$ guru sudah mendapatkan katagori baik dengan skor rata-rata 80 - 89.Hal ini sudah sesuai dengan kriteria keberhasilan yang ditetapkan. Secara rinci perolehan nilai rata-rata peningkatan kemampuan guru memanfaatkan lingkungan sekolah sebagai sumber belajar yaitu nilai rata-rata observasi hasil kegiatan diskusi 79,38 di siklus I menjadi 84,88 di siklus II ada peningkatan 5,5. kegiatan penyusunan skenario pembelajaran nilai rata-rata 78,75 di siklus I menjadi 82,50 di siklus II ada peningkatan 3,75, kegiatan pembelajaran atau dalam proses belajar mengajar nilai rata-rata 78,33 di sklus I menjadi 82,08 di siklus II, ada peningkatan 3,75 .

\section{Kesimpulan}

Berdasarkan hasil analisis dan pembahasan siklus I dan siklus II tersebut di atas, maka dapat disimpulkan bahwa:

Ada peningkatan kemampuan guru dalam memanfaatkan lingkungan sekolah sebagai sumber belajar melalui supervise akademik di SMK Sabilal Muhtadin Balikpapan.

\section{Saran}

Kepada.guru-guru khususnya guru di SMK Sabilal Muhtadin Balikpapan, di dalam menyusun skenario pembelajaran agar memanfaatkan semaksimal mungkin lingkungan sekolah dan lingkungan siswa yang sesuai dengan materi pembelajaran sebagai sumber belajar,dan mengintensifkan supervise akademik dalam memecahkan masalah yang dihadapi.

\section{Daftar Pustaka}

Badru Zaman, dkk. 2005. Media dan Sumber Belajar TK. Buku Materi Pokok PGTK 2304. Modul 1-9. Jakarta Universiats Terbuka.

Ekowati, Endang. 2001. Stategi Pembelajaran Kooperatif. Modul Pelatihan Guru Terintegrasi Berbasis Kompetensi. Jakarta : Depdiknas.

Mulyasa,E.2004.Menjadi Kepala Sekolah Profesional,Remaja Rosdakarya,Bandung.

Purwanto,M.Ngalim,2004.Administrasi dan Supervisi Pendidikan ,Remaja Rosdakarya,Bandung

Rusyan Tabrani. 2001. Pendekatan dalam Proses Belajar Mengajar. Bandung Remaja Rosdakarya.

Sahertian,2000,Supervisi Pendidikan ,Reneke,Jakarta 